\title{
Exploring the Impact of Service Quality on Online Customer Loyalty
}

\author{
Meng-Chen Lin ${ }^{1 *}$, Ya-Ping Chiu ${ }^{2}$, Chih-Hsuan Huang ${ }^{1}$, Yu-Ping $\mathrm{Wu}^{1}$ \\ ${ }^{1}$ School of Business Administration, Hubei University of Economics, No.8, Yanghu Avenue, Canglongdao \\ Development Zone, Jiangxia District, Wuhan City, Hubei Province, China. \\ 2 Department of Business Administration, Chung Yuan Christian University, 200 Chung Pei Road, Chung Li \\ District, Taoyuan City, Taiwan.
}

* Corresponding author. Tel.: +86 15994262076; email: mengchen0608@gmail.com

Manuscript submitted April 24, 2017; accepted June 2, 2017.

doi: 10.17706/ijeeee.2017.7.4.230-238

\begin{abstract}
With the development of science and technology in an environment of constant innovation, online shopping has become a major consumer trend of the times. A survey done by the Institute for Information Industry showed that the total Internet transactions of Taiwan reached NTD 1127.8 billion in 2016, suggesting that e-commerce is continuously expanding. This study utilized consumers of online bookstores as research subjects to explore the impact of website service quality on customer loyalty, as well as the influence of asset specificity on the relationship between service quality and customer loyalty. The results revealed that enhancing website convenience, providing preferential prices, reinforcing website security, designing easy-to-use interfaces and functionalities, and increasing flexibility of customer service could improve service quality, thereby substantially increasing customer loyalty. In addition, the establishment and strengthening of asset specificity of the website to its customers can help facilitate customers' awareness of service quality, thereby increasing customer loyalty.
\end{abstract}

Key words: Service quality, customer loyalty, asset specificity

\section{Introduction}

In the environment of scientific and technological development and innovation, online shopping has become a current trend for consumption. Research conducted by the Institute for Information Industry showed that online business-to-customer (B2C) and customer-to-customer (C2C) transactions in Taiwan amounted to NTD 687.5 billion and NTD 440.3 billion in 2016, respectively, indicating that the Internet has become an indispensable consumption channel of modern life. The business model of e-commerce has transformed from a business-to-business (B2B) model to more diversified models, such as B2C and C2C. With the continuous progress of e-commerce and Internet technology, the number of online stores has increased and many companies have attempted to seize new market opportunities, as well as utilize online marketing campaigns. Due to the advantages offered by the Internet, such as $24 / 7$ operational hours, no geographical or spatial limitations, easy-to-find products, and lower prices, many physical stores have also shifted their business onto the Internet to open online stores, creating intense competition for online marketplaces. Therefore, it is of vital importance to evaluate and improve the business performance of online stores to increase customer loyalty. Increasing customer loyalty leads to increased financial revenue, reduced customer service costs, and thus, greater profits [1]. Moreover, improving service quality can also 
improve customer retention rates, thereby generating more business through direct sales. [2] study showed that customers' recognition of service quality could affect companies' earnings and profits; the recognition of customers is the primary factor influencing loyalty [3], [4]. On that account, improving investment decisions through improved service quality in order to strengthen customer loyalty is of great significance to businesses [5]. Previously, many studies have examined the impact of service quality on customer loyalty in a traditional business context [6], [7]. The advent of the Internet era makes online shopping a prevailing force. Purchasing activities are no longer restricted to physical stores and consumers are able to buy products without having to ever leave their home. Similar to the traditional business environment, online shopping also involves the recognition of the store's service quality by consumers, which influences purchase intention, and even re-purchase intention. Hence, some studies have begun to explore the impact of service quality on customer loyalty on online platforms [1]. Since Loiacono, Watson, and Goodhue put forward WebQualTM, a tool to assess website quality, the service quality of websites has become an important research topic. Utilizing the above research background and motivating reasons, this study employed consumers from online bookstores as research subjects to explore: (1) the influence of website service quality on customer loyalty and (2) the effect of asset specificity on the relationship between service quality and customer loyalty.

\section{Theoretical Foundations}

\subsection{Service Quality}

Ref. [8] suggested that the level of consumers' satisfaction toward service reflects the quality of service, which depends on the discrepancies between actual service performance and consumers' original expectations. Ref. [9] claimed that a simpler definition of service quality is whether an enterprise can meet the needs of its customers. ref. [10] defined service quality as a holistic evaluation of service superiority, whilst superiority implies that the actual service quality exceeds the expectations of consumers. The most commonly cited concepts regarding the characteristics of service quality were proposed by [10], who inferred the following three characteristics: 1) To a customer, the quality of a service is more difficult to evaluate compared to that of a product. For this reason, some people consider price and other factors to be important indicators of service. 2) Service quality can be defined as the difference between customers' expectations and their actual experience of a service process, which thereby influences their trust and loyalty towards the brand. 3) The evaluation of service quality should include not only outcomes but also the processes involved in service delivery.

\subsection{Customer Loyalty}

Ref. [11] pointed out that customer loyalty is the customer's intention to re-purchase a particular product or service in the future. They also suggested that customer loyalty could be divided into long-term and short-term loyalty. Long-term loyalty refers to a customer's long-term, consistent selection of a particular product/service, which is not easy to alter. Short-term loyalty implies customers may be attracted by a better vendor or product under the right circumstances and may therefore shift their loyalty. Ref. [12] claimed that customer loyalty is the customer's satisfaction towards companies' goods or services, to the point that their customers become willing to advertise on behalf of the company, thereby creating a positive word-of mouth effect. Ref. [13] believed that customer loyalty is the key factor that determines the likelihood of customers re-purchasing behavior. Ref. [14] suggested four indicators of customer loyalty: customers' intention to repurchase, willingness to recommend the company and the brand to others, having a higher price tolerance, and having cross-buying intentions. Past surveys have pointed out that in order to earn profits from online customers, the customers should purchase from the online store at least four times 
and be retained by the business for more than 18 months before the business can break even [15]. This finding suggests that the cost of acquiring new customers on the Internet is higher than the cost of acquiring new customers from traditional channels. Therefore, maintaining customer loyalty, resulting in repeat customers, is of great importance for online businesses.

\subsection{Service Quality and Customer Loyalty}

Ref. [10] pointed out that service quality can influence customer loyalty and that improving the quality of service can help companies develop customer loyalty, indicating that a positive correlation exists between service quality and customer loyalty. Many scholars have suggested that service quality can affect customers' behavioral intentions and good service quality can increase customer loyalty [4], [16]. Online stores are known to have different features when compared to traditional physical stores. To determine what those features are, assessed and determined a set of criteria to be used in the evaluation of website service quality. This study utilized the SERVQUAL scale as a base and referred to the multi-item scale proposed by [17] to measure the service quality of websites. According to [17], website service quality can be divided into seven dimensions: convenience, price consideration, safety and reliability, website design, easy-to-operate functionalities, customization, and flexibility. Hence, this study intends to investigate the relationship between the seven dimensions and customer loyalty respectively and proposes the following hypotheses:

H1a: The convenience of a website has a significant, positive impact on customer loyalty.

H1b: The website's product price has a significant, positive impact on customer loyalty.

H1c: The safety and reliability of a website has a significant, positive impact on customer loyalty.

H1d: The website design has a significant, positive impact on customer loyalty.

H1e: The degree that functionalities of a website are seen as easy to use has a significant, positive impact on customer loyalty.

H1f: The degree of customization a website permits has a significant, positive impact on customer loyalty. H1g: The degree of flexibility in the service of a website has a significant, positive impact on customer loyalty.

\subsection{Service Quality, Customer Loyalty, and Asset Specificity}

Ref. [18] proposed the concept of asset specificity, which refers to a close link between a special resource or asset and other resources (or assets), which is difficult to be shifted or divided without potentially losing value. According to Williamson, such assets are connected to a company and can only be acquired through the company. Even if other companies are able to acquire the corresponding resources, they are not able to imitate the specific functional methods of application of the resource. When assets specificity is established between consumers and online stores, consumers have to consider the costs and risks involved in the loss of long-established asset specificity when changing the store or brand. There are various forms of asset exclusivity, including human asset specificity, site specificity, physical asset specificity, and time specificity. In the case of information technology, both knowledge specificity and time specificity play an influence. Since individuals' access to information, use of information, and conceptualization of previous problems are based on their personal experiences and previous knowledge, knowledge specificity is one form of information specificity. A website can be seen as being asset-specific to the customer when he/she becomes familiar with the interface and functionalities of the website. The greater the asset-specific a website is to a customer, the more the customer becomes accustomed to the operational processes and procedures of the website; therefore, the conversion costs of shifting to other websites are likely to be higher. On that account, asset specificity of a website can enhance the positive correlations between service quality and customer loyalty. Hence, we proposed our second hypothesis , and Figure 1 illustrates the research framework.

H2: Asset specificity can enhance the positive influences of service quality on customer loyalty. 


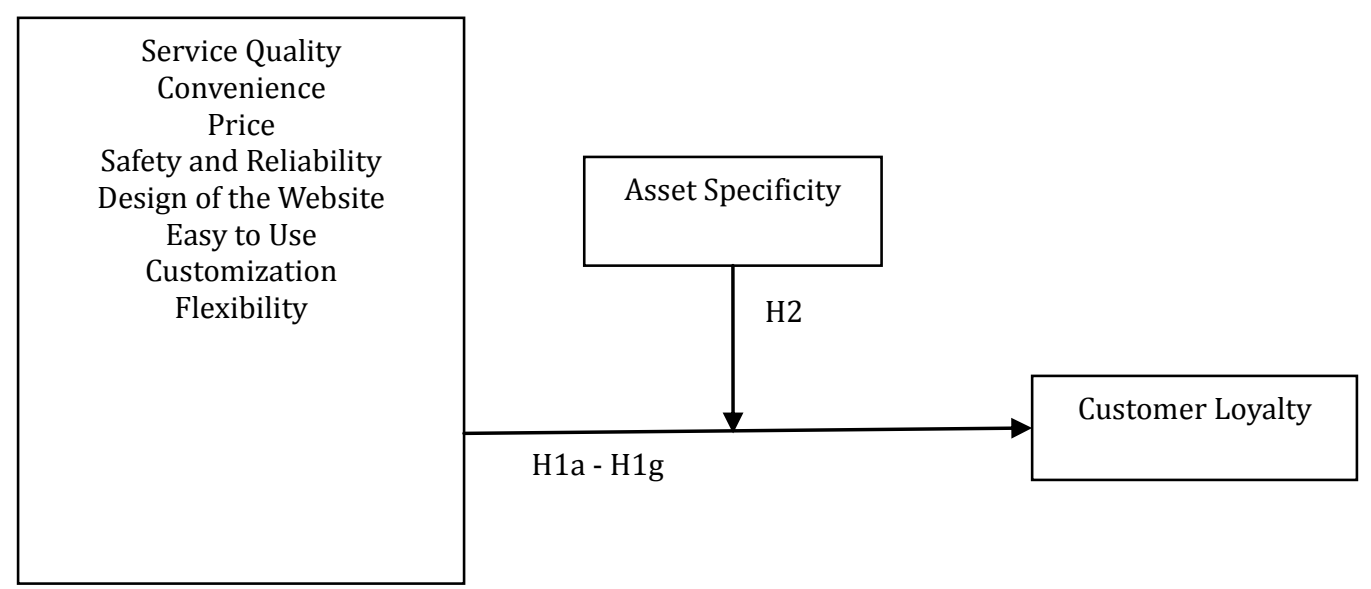

Fig. 1. Research framework.

\section{Method}

The variables were defined and operationalized based on the research framework. Service quality in this study referred to customers' direct perceptions of service quality during the service delivery process, as well as the outcomes of the corresponding services. Customer loyalty was defined as customers' intention to invest time and effort to maintain the current relationship with the service providers [19], [20] customer loyalty scale was introduced to measure the loyalty of the customers in this study. The scale developed by [17] was adopted for the evaluation of the service quality of online stores. The scale developed by [21] was employed to measure asset specificity. All scales adopted a five-point Likert scale.

The research subjects of the study were customers of online bookstores who had previous online shopping experience within six months prior to the study. A questionnaire containing the aforementioned scales was utilized to collect data regarding their shopping experience, perceived website service quality, and website loyalty. A total of 157 questionnaires were distributed. Excluding unqualified responses, 112 valid questionnaires were collected, yielding an effective recovery rate of $78 \%$. The collected information was then entered into SPSS 18.0 for further analyses, to determine the impact of website service quality on customer loyalty, as well as the role asset specificity plays in the relationship between service quality and customer loyalty.

\section{Results}

\subsection{Reliability and Validity Analyses}

Ref. [22] claimed that a Cronbach's $\alpha$ of greater than 0.5 could be considered acceptably reliable; suggested that a Cronbach's $\alpha$ between 0.7 and 0.8 can be seen as highly reliable, and a result greater than 0.8 can be regarded as an ideal result. The Cronbach's $\alpha$ values of price (0.5251), customization (0.5853), and asset specificity (0.6264) were greater than 0.5 , and that of convenience $(0.7631)$, safety and reliability (0.7980), website design (0.7597), easy-to-use functionalities (0.7813), flexibility of service (0.8152), and customer loyalty $(0.7905)$ were greater than 0.7 , suggesting that the reliability of the scales were relatively good. The factor structure analysis results of the variables were greater than 0.6 , indicating good validity.

\subsection{Demographical Statistics}

Among the respondents, 58 were female (52\%) and 54 were male (48\%). The majority of the respondents were aged between 20 and 25 years old (53=53\%), followed by those under 20 years $(17=15 \%)$ and by those between 26 and 30 years $(16=16 \%)$. Nearly three quarters of the respondents had at least 
received undergraduate education $(81=72 \%)$, and the number of college graduates ranked second $(12=11 \%)$. More than half the respondents were students $(61=54 \%)$, followed by the respondents that worked in service industries $(24=21 \%)$ and manufacturing industries $(14=13 \%)$. The majority of the respondents had been using online shopping for more than 7 years $(59=53 \%)$ followed by a use of between 5 to 7 years $(21=19 \%)$.

\subsection{Regression Analyses}

Regression analyses were then applied to explore the impact of service quality on customer loyalty. Convenience was found to be significantly, positively correlated to customer loyalty $(\beta=.185, p<.05$ ), suggesting that the greater the convenience, the more loyal the customers will be. Price and customer loyalty were found to have strong positive correlation $(\beta=.123, p<.10)$, indicating that the higher the price, the greater the loyalty of customers. Safety and reliability appear to have a substantial positive impact on customer loyalty $(\beta=.279, p<.01)$, showing that the greater the safety and reliability of a website, the more loyal the customers will be. The design of the websites was found to have no apparent impact on customer loyalty $(\beta=-.0031, p>.10)$, indicating that the quality of website design does not affect customer loyalty. Ease of use of website functionalities appeared to have a significant, positive effect on customer loyalty ( $\beta$ $=.301, p<.01)$, implying that the easier a website is to use, the higher the customer loyalty. No notable correlation was found between customization and customer loyalty $(\beta=.0031, p>.10)$, which indicates that customizing the website for each user does not influence customer loyalty. There was a noticeably positive correlation between flexibility of service and customer loyalty $(\beta=.134, p<.10)$, suggesting that the greater the flexibility of service a website provides, the more likely the customers are to be loyal to the website (Table 1 and Table 2).

Table 1. Relationship between Service Quality and Customer Loyalty

\begin{tabular}{|c|c|c|}
\hline Variables & Model 1 & Model 2 \\
\hline \multicolumn{3}{|l|}{ Independent Variables } \\
\hline Convenience & & $0.185(2.045)^{* *}$ \\
\hline Price & & $0.123(1.815)^{*}$ \\
\hline Safety and Reliability & & $0.279(2.884)^{* * *}$ \\
\hline Website design & & $-0.0031(-0.322)$ \\
\hline Ease of Use & & $0.301(3.671)^{* * *}$ \\
\hline Customization & & $0.0031(0.335)$ \\
\hline Flexibility & & $0.134(1.184)^{*}$ \\
\hline \multicolumn{3}{|l|}{ Control Variables } \\
\hline Age & $0.0008(0.021)$ & $0.012(0.35)$ \\
\hline Year in Service of the Website & $0.094(2.442)^{* *}$ & $0.003(0.757)$ \\
\hline $\mathrm{R}^{2}$ & 0.061 & 0.490 \\
\hline Adjusted $\mathrm{R}^{2}$ & 0.042 & 0.437 \\
\hline F ratio & $3.080^{*}$ & $9.271^{* * *}$ \\
\hline
\end{tabular}

Remark: $\mathrm{N}=112$; the results of t-test were listed in brackets; ${ }^{*} \mathrm{p}<.10,^{* *} \mathrm{p}<.05,{ }^{* * *} \mathrm{p}<.01$.

Table 2. Influence of Asset Specificity on the Relationship between Service Quality and Customer Loyalty

\begin{tabular}{|c|c|c|c|c|c|c|c|c|}
\hline Variables & Model 1 & Model 2 & Model 3 & Model 4 & Model 5 & Model 6 & Model 7 & Model 8 \\
\hline $\begin{array}{l}\text { Independent } \\
\text { Variables }\end{array}$ & & & & & & & & \\
\hline Convenience & & $\begin{array}{l}0.260 \\
(2.415)^{* *}\end{array}$ & & & & & & \\
\hline $\begin{array}{l}\text { Asset Specificity } \\
\times \text { Convenience }\end{array}$ & & $\begin{array}{l}0.044(2.700)^{* *} \\
*\end{array}$ & & & & & & \\
\hline
\end{tabular}




\begin{tabular}{|c|c|c|c|c|c|c|c|c|}
\hline \multirow{2}{*}{$\begin{array}{l}\text { Price } \\
\text { Asset Specificity } \\
\times \text { Price }\end{array}$} & & & \multirow{2}{*}{$\begin{array}{l}-0.096 \\
(-0.848) \\
0.0623 \\
(2.907)^{* *} \\
*\end{array}$} & & & & & \\
\hline & & & & & & & & \\
\hline $\begin{array}{l}\text { Safety and } \\
\text { Reliability }\end{array}$ & & & & $\begin{array}{l}0.209 \\
(1.970)^{*}\end{array}$ & & & & \\
\hline $\begin{array}{l}\text { Asset Specificity } \\
\times \text { Reliability }\end{array}$ & & & & $\begin{array}{l}0.044 \\
(2.432)^{*} \\
*\end{array}$ & & & & \\
\hline Website Design & & & & & $\begin{array}{l}0.123 \\
(1.068)\end{array}$ & & & \\
\hline $\begin{array}{l}\text { Asset Specificity } \\
\times \text { Design of the } \\
\text { Website }\end{array}$ & & & & & $\begin{array}{l}0.051 \\
(2.660)^{* *} \\
*\end{array}$ & & & \\
\hline Ease of Use & & & & & & $\begin{array}{l}0.276 \\
(2.537)^{* *}\end{array}$ & & \\
\hline $\begin{array}{l}\text { Asset Specificity } \\
\times \text { Easy to Use }\end{array}$ & & & & & & $\begin{array}{l}0.039 \\
(2.229)^{* *}\end{array}$ & & \\
\hline $\begin{array}{l}\text { Customization } \\
\text { /Individualizatio } \\
\mathrm{n}\end{array}$ & & & & & & & $\begin{array}{l}0.126 \\
(1.045)\end{array}$ & \\
\hline $\begin{array}{l}\text { Asset Specificity } \\
\times \text { Customization / } \\
\text { Individualization }\end{array}$ & & & & & & & $\begin{array}{l}0.048 \\
(2.310)^{*} \\
*\end{array}$ & \\
\hline Flexibility & & & & & & & & $\begin{array}{l}0.126 \\
(1.331)\end{array}$ \\
\hline $\begin{array}{l}\text { Asset Specificity } \\
\times \text { Flexibility }\end{array}$ & & & & & & & & $\begin{array}{l}0.054 \\
(2.965)^{* *} \\
*\end{array}$ \\
\hline \multicolumn{9}{|l|}{ Control Variables } \\
\hline Age & $\begin{array}{l}0.001 \\
(0.021)\end{array}$ & $\begin{array}{l}0.004 \\
(0.103)\end{array}$ & $\begin{array}{l}0.006 \\
(0.166)\end{array}$ & $\begin{array}{l}0.026 \\
(0.749)\end{array}$ & $\begin{array}{l}0.013 \\
(0.347)\end{array}$ & $\begin{array}{l}-0.015 \\
(-0.429)\end{array}$ & $\begin{array}{l}0.013 \\
(0.358)\end{array}$ & $\begin{array}{l}0.011 \\
(0.301)\end{array}$ \\
\hline $\begin{array}{l}\text { Number of Years } \\
\text { the website has } \\
\text { been operating } \\
\text { Website }\end{array}$ & $\begin{array}{l}0.094 \\
(2.442)^{*} \\
*\end{array}$ & $\begin{array}{l}0.008 \\
(0.234)\end{array}$ & $\begin{array}{l}0.086 \\
(2.477)^{* *}\end{array}$ & $\begin{array}{l}0.063 \\
(1.976)^{*}\end{array}$ & $\begin{array}{l}0.079 \\
(2.388)^{* *}\end{array}$ & $\begin{array}{l}0.076 \\
(2.412)^{* *}\end{array}$ & $\begin{array}{l}0.083 \\
(2.530)^{*} \\
*\end{array}$ & $\begin{array}{l}0.080 \\
(2.423)^{* *}\end{array}$ \\
\hline $\mathrm{R} 2$ & 0.061 & 0.278 & 0.150 & 0.269 & 0.197 & 0.294 & 0.208 & 0.250 \\
\hline Adjusted R2 & 0.042 & 0.250 & 0.117 & 0.240 & 0.166 & 0.265 & 0.177 & 0.220 \\
\hline $\mathrm{F}$ ratio & $3.080^{*}$ & $9.899 * * *$ & $4.505^{* * *}$ & $9.290^{* * *}$ & $6.314^{* * *}$ & $\begin{array}{l}10.285^{* *} \\
*\end{array}$ & $6.692^{* * *}$ & $8.335^{* * *}$ \\
\hline
\end{tabular}

Remark: $\mathrm{N}=112$; the results of t-test were listed in brackets; ${ }^{*} \mathrm{p}<.10,{ }^{* *} \mathrm{p}<.05,{ }^{* * *} \mathrm{p}<.01$.

\section{Discussion}

The purpose of this study was to explore the relationship between various dimensions of service quality and customer loyalty, and the results of the hypothesis tests are presented in Table 3.

Table 3. Hypothesis Test Results

\begin{tabular}{ll}
\hline Hypotheses & Results \\
\hline H 1: The service quality of a website has a significant positive impact on customer loyalty. & Partially supported \\
H1a: The convenience of a website has a significant impact on customer loyalty. & Supported \\
H1b: The product price of a website has a significant impact on customer loyalty. & Supported \\
H1c: The safety and reliability of a website has a significant impact on customer loyalty. & Supported \\
\hline
\end{tabular}




\begin{tabular}{ll}
\hline H1d: The ease of use of functionalities has a significant impact on customer loyalty. & Supported \\
H1e: The website design has a significant impact on customer loyalty. & Rejected \\
H1f: The customization of a website has a significant impact on customer loyalty. & Rejected \\
H1g: The flexibility the service of a website has a significant impact on customer loyalty. & Supported \\
H2: Asset specificity can enhance the positive influence of service quality on customer loyalty. & Supported \\
\hline
\end{tabular}

According to the findings, the service quality of online bookstores is a vital influencing factor of customer loyalty. Convenience, price, safety, and reliability, ease of use, and flexibility of service were found to have a strong positive impact on customer loyalty. Website design and degree of customization were found to have no apparent influence on customer loyalty.

The reasons that customization was found to have no noticeable impact on customer loyalty could be attributed to the fact that the study respondents were users of online bookstores. Since books tend to have standardized features, they are not perceived as customizable goods by the respondents. Therefore, the degree of customization was not notably influential to customer loyalty. In addition, website design was also found to have little impact on customer loyalty. A possible explanation could be that customers of online bookstores mainly visit these websites to purchase books and have less demand for leisure, entertainment, or information services. For this reason, the novelty and advanced functionalities of the websites were not considered a key factor by customers, and therefore had little impact on their loyalty. Moreover, it was found that when customers are familiar with the method of shopping and service provided by an online store, they are less likely to turn to other stores. From traditional face-to-face purchasing experiences to shopping through a technological interface on the Internet, the delivery of services shifted from traditional channels to technology. Therefore, website service quality has a significant impact on consumer loyalty. In addition, once customers are accustomed to the functionalities and usage of a website, high asset specificity of the website itself can enhance the relationship between service quality and customer loyalty.

\section{References}

[1] Reichheld, F. F. (1993). Loyalty-based management. Harvard Business Review, 71(2), 64-73.

[2] Zeithaml, A. (2000). Service quality, profitability, and the economic worth of customer: What we know and what we need to learn. Journal of the Academy of Marketing Science, 28, 67-85.

[3] Fornell, C. (1992). A national customer satisfaction barometer: The Swedish experience. Journal of Marketing, 56(1), 6-21.

[4] Cronin, J. J., Brady, M. K., \& Hult, G. T. M. (2000). Assessing the effects of quality, value, and customer satisfaction on consumer behavioral intentions in service environments. Journal of Retailing, 76(2), 193-218.

[5] Chao, P. (2008). Exploring the nature of the relationships between service quality and customer loyalty: An attribute-level analysis. The Service Industries Journal, 28(1), 95-116.

[6] Berry, L. L., Parasuraman, A., \& Zeithaml, V. A. (1988). The service-quality puzzle. Business Horizons, 35-43.

[7] Berry, L. L., Parasuraman, A., \& Zeithaml, V. A. (1994). Improving service quality in America: Lessons learned. Academy of Management Executive, 32-52.

[8] Churchill, G., \& Suprenant, C. (1982). An investigation into the determinants of consumer satisfaction. Journal of Marketing, 18(4), 36-44.

[9] Juran, J. M.(1989). Juran on Leadership for Quality: An Executive Handbook. Juran Institute, Wilson, C.T.

[10] Parasuraman, A., Zeithaml, V. A., \& Berry, L. L. (1985). A conceptual model of service quality and its implications for future research. Journal of Marketing, 49, 41-50.

[11] Jones, T. O., \& Sasser, W. E. (1995). Why satisfied customers defect. Harvard Business Review, 73(6), 88-99. 
[12] Bhote. (1996). The Key to Greater Profitability. New York: American Management Association.

[13] Bowen, J., \& Shoemaker, S. (1998). Loyalty: A strategic commitment, cornell hotel and restaurant. Administration Quarterly, 39(1), 12-25.

[14] Gronholdt, L., Martensen, A., \& Kristensen, K. (2000). The relationship between customer satisfaction and loyalty: Cross-industry differences. Total Quality Management, 11, 509-516.

[15] Bain \& Mainspring, C. (2000). eStrategy brief the value of online customer loyalty. [One in series of papers on e-commerce topics published by Bain and Company and Mainspring].

[16] Parasuraman, Z., \& Berry. (1994). Moving forward in service quality research: Measuring different customer-expectation levels, comparing alternative scales, and examining the performance-behavioral intentions link. Marketing Science Institute, 94-114.

[17] Chang, C. C. (2001). A multiple-item scale to measure service quality on internet shopping. College of Management, Yuan Ze University.

[18] Williamson, O. E. (1985). Reflections on the New Institutional Economics, 187-195.

[19] Zeithaml, A. V., Berry, L. L., \& Parasuraman, A. (1996). The behavioral consequences of service quality, Journal of Marketing, 60(2), 31-46.

[20] Duh, P. L. (2001). Customer's trust model and customer loyalty in web shopping. College of Management, Yuan Ze University.

[21] Tseng, S. F., \& Chang, S. S. (2002). The relationship between electronic store quality model. Information Management, 4(1), 15-42.

[22] Churchill, G., \& Moschis, G. (1979). Television and interpersonal influences on adolescent consumer learning. Journal of Consumer Research, 6, 23-35.

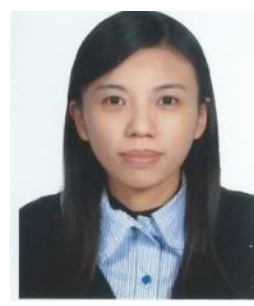

Meng-Chen Lin is a lecturer in the School of Business Administration at Hubei University of Economics, Wuhan city, China. She received her Ph.D. in marketing management from Yuan Ze University, Taiwan in 2016. Her research in these areas has appeared in a Journal of Marketing Management, Chung Yuan Management Review, etc. Her research interests include consumer behavior, relationship marketing, internet marketing, and marketing strategy.

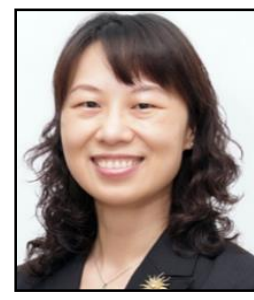

Ya-Ping Chiu (PhD, National Chengchi University) is an associate professor of the Department of Business Administration at Chung Yuan Christian University in Taiwan. Her research interests include expatriate management, governance and coordination in multinational enterprise, and knowledge transfer. She has published in the International Journal of Human Resource Management, Journal of Knowledge Management, Asia Pacific Journal of Management, NTU Management Review (in Chinese), and Journal of Human Resource Management (in Chinese).

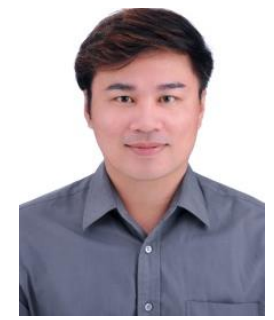

Chih-Hsuan Huang received his Ph.D. in consumer behavior from Queensland University of Technology, Brisbane, Australia in 2013. He is a Lecturer in the School of Business Administration at Hubei University of Economics, Wuhan City, China.

He was elected as an International Economics Development Research Center (IEDRC) Fellow Member in Jan. 2016. He is a Technical Program Committee for 2017 International Conference on Economic Development and Enterprise Innovation (EDEI) and 2017 International Conference on Financial Technology (ICFT). Moreover, he serves as Reviewer for INQUIRY: The Journal of Health Care Organization, Provision, and Financing (indexed in Science Citation Index). His 
research in these areas has appeared in a journal such as Asia Pacific Journal of Marketing and Logistics, International Journal of Health Care Quality Assurance, Journal of Management Research, Asia Journal of Business and Management, Journal of Computing and Information Science in Engineering, etc. His research interests include green consumer behavior, relationship marketing, sustainable management and patient safety.

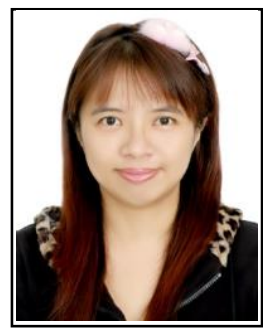

Yu-Ping Wu is a lecturer in the School of Business Administration at Hubei University of Economics, Wuhan City, China. She earned her Ph.D. degree from National Dong Hwa University in 2016. Her research areas include Marketing Management, E-Commerce, Lean Service and Strategic. She has published 19 papers at international and domestic academic journals and conferences. 